\title{
Impulsivity: A Case Study of Jordanian Women
}

\author{
MOHAMMAD I. OBEIDAT \\ Assistant Professor \\ Department of Business Administration \\ Faculty of Economics and Administrative Sciences \\ University of Jordan, Amman, Jordan.
}

\begin{abstract}
The objective of this study is to measure women's impulsivity in Jordan and its expected impact on their consumption patterns.

The study sample consisted of 328 women. They have been selected from various Jordanian cities and towns, according to certain conditions set for this study.

The study showed the following results:

First, married women appear to be more impulsive in their shopping behavior than divorced women.

Second, women's impulsivity increases as the level of their educational attainment and occupational status increases.

Finally, women's impulsivity increases as women become older and older.
\end{abstract}

\section{Introduction}

Impulsivity is one of the major factors in a dimensional system of personality. The construct of impulsivity is subdivided into various dimensions, including risk-taking, non-planning, liveliness and spontaneity ${ }^{(1)}$.

Although impulsivity is an important variable from the standpoint of segmentation, there has been a complete absence of conceptual and empirical study regarding the behavioral outcomes of impulsivity on Jordanian women's consumption patterns. The objective of this study is to explore women's impulsivity and its possible effects on their consumption patterns in the marketplace.

(1) a. S.B.G. Eysenck and J. H. Eysenck, The place of impulsiveness in a dimensional system of personality description, Journal of Sociology and Clinical Psychology, (1977)57-68.

b. Paul John Newport, Profits in Costoffs, Fortune, September, 30, (1985)75-77. 
This study represents an initial and exploratory effort to start building the necessary psychological body of information dealing with Jordanian women's impulsivity into the area of consumer behavior.

\section{Related Literature}

In psychological literature, the term "impulsiveness" tends to be assigned rather broadly to a variety of different behavioral patterns ${ }^{(2)}$. Some notions of impulsiveness refer to actions on the spur of the moment, to a lack of reflectiveness and planning, to the degree of rapidity of decisions and actions or to the lack of consideration of the effects of one's actions ${ }^{(3)}$.

Psychological impulsivity as such has been tentatively linked to aggression, sensation seeking and sociability. Although it is found to be influenced by age and gender, however, it has not been found to be influenced by social class ${ }^{(4)}$. In consumer behavior, impulse buying has been associated with unplanned purchase ${ }^{(5)}$. Such a behavioral approach, which disregards the psychological causes underlying such action, has only recently been replaced by an in-debted study of impulsiveness. Thus, impulse buying is seen as "encompassing purchases with high emotional activation/ low cognitive control and a largely reactive behavior ${ }^{(6)}$ ", thus empirically validating the role of emotions in the decision process. Rook and $\operatorname{Hock}^{(7)}$ identify five crucial elements in impulse buying: a sudden and spontaneous desire to act, a state of psychological disequilibrium, the onset of psychological conflict and struggle, a reduction in cognitive evaluation, and a lack of regard for the consequences of impulse buying.

Impulse buyers (those scoring high on an eighth-item scale) were more likely to prefer shopping at night and by phone. Females were more impulsive than males, as were younger people who were seen to be more impulsive than older people. Therefore, there have been no research efforts in either the psychological or consumer behavior literature to examine women's impulsivity in Jordan, specifically, examining how changes in women demographic positions are related to their impulsivity.

\section{Hypotheses}

To the degree that some demographic factors build relatively different behavioral orientation in women, it should be expected that women will have different degrees of impulsivity. For example, as divorce builds apprehensiveness in women ${ }^{(8)}$, it should be

(2) a. D. Schalling, Psychopathic Behavior: Personality and Neuropsychology, paper given to the advanced study of behavior, Institute of Psychopathic Behavior, Les-Arcs, France, (1975).

b. W. Dennis Rook, The Buying Impulse, Journal of Consumer Research, 14, September, (1987)189-216.

(3) a. N. Barret, Women in the Job Market: Occupation Earnings, and Career Opportunities, in: R. E. Smith (ed.), The Subtle Revolution, Washington, D.C.: The Urban Institution, (1979) 31-61.

b. A. Sobczynski, Inside the Store: the selling Never Stops, Advertising Age, March 15, (1982), 30-33.

(4) Eymck, 1977, op. cit., pp. 57-68.

(5) a. H. Stern, The Significance of Impulse Buying Today. Journal of Marketing, 26, (1962) 59-62.

b. Henry Asseal, Consumer Behavior and Marketing Action, Second edition, Kent Publishing Company, (1984) 559-562.

(6) P. Weinberg and W. Gootwald, Impulsive Consumer Buying as a result of Emotions, Journal of Business Research, 10, (1982) 43-57.

(7) H. Rook and A. Hock, Impulse Buying; Advances in Consumer Research, Vol. 10, (1983) 562-567.

(8) C. Kitson, Karen Benson Babri and Joan Mary Roach, Who Divorces and Why? A Review, Journal of Family Issues, 6,(3), September, (1985) 255-293. 
expected that divorced women will become more cautious in their choices of products, brands and buying situations, as compared to married women. The unique experience of divorce to those who are involved - may lead to various defense mechanisms, including a longer deliberation and avoidance of acting on impulsive in any future choice situation such as shopping.

Therefore, it is hypothesized that:

H1. Divorced women will be less impulsive in their shopping behavior as compared to married women.

Levinger ${ }^{(9)}$ suggested that women usually have different levels of income, therefore, it should be expected that women's impulsivity will vary according to their available resources. Further, it is likely to suggest that impulsivity may be correlated with such variables as educational attainment, occupational status and marital status as well ${ }^{(10)}$. Therefore, it would seem more plausible to propose that impulsivity is not a genetic constant, but rather is socially influenced by many variables such as income, marital status, educational attainment and occupational status. On the basis of the above, the following hypotheses are suggested:

H2 Women's impulsivity will vary according to their educational attainment.

H3 Women's impulsivity will vary according to their occupational status.

H4 Women's impulsivity will vary according to their age categories.

\section{The Sampling}

\section{Research Methodology}

The data was collected from a convenience sample and according to the following conditions:

- Female head of household between 25-45 years of age.

- Female head of household employed full-time with a total annual household income of 1000 to 6000 J.D. or more.

- Presence of at least one child between the ages of 5 and 16.

- Female head of household with a minimum educational level of high school graduate.

On January 30, 1988 the researcher mailed 658 questionnaires to the sample selected according to conditions above-mentioned. On March 18, 1988, the study was completed with 417 returns (63.5\% of mailout). Eighty-nine questionnaires were excluded because they were either incomplete or did not meet some of the criteria set for the sample. A total of 328 out of 658 submitted usable questionnaires were entered into the analysis, representing $50.0 \%$ of the total number of subjects contacted.

(9) a. G. Levinger, A Social Psychological Perspective on Marital Dissolution, Journal of Social Issues, 32 , (1), (1976) 21-47.

b. Skelly Yankelovich and Inc. White, Supermarket shoppers in a period of economic uncertainty, (1982)53

(10) a. Elizabeth Hirschman, C., Innovativeness, Novelty seeking and Consumer Creativity, Journal of Consumer Research, Vol. 7, December (1980) 283-295.

b. Amy Duncan, No-Frills Products: An Idea Whose Time has Gone, Business Week, June 17, (1985) 64-67. 


\section{Measurement}

For this study, the measurement instrument developed by Eysenck and Eysenck ${ }^{(11)}$ was adopted. As shown below, a list of 14 items or statements relating to consumer impulsiveness are evaluated by use of a five-point scale. This scaler has been validated through many empirical studies by Eysenck and Eysenck ${ }^{(12)}$ and this author in 1987.

\begin{tabular}{|l|l|l|l|l|l|}
\hline \multicolumn{1}{|c|}{ Item } & $\begin{array}{c}\text { Very true } \\
\text { of me. }\end{array}$ & $\begin{array}{c}\text { Quite true } \\
\text { of me }\end{array}$ & $\begin{array}{l}\text { Somewhat } \\
\text { true of me }\end{array}$ & $\begin{array}{c}\text { Not very } \\
\text { true of me }\end{array}$ & $\begin{array}{c}\text { Not at all } \\
\text { true of me }\end{array}$ \\
\hline - I often buy things on impulse. & & & & & \\
\hline $\begin{array}{c}\text { - I usually consider all the possibilities } \\
\text { before making a decision. }\end{array}$ & & & & & \\
\hline $\begin{array}{c}\text { - I often do things on the spur of the } \\
\text { moment. }\end{array}$ & & & & & \\
\hline - I take things too seriously. & & & & \\
\hline $\begin{array}{l}\text { - I have a great deal of drive and } \\
\text { ambition. }\end{array}$ & & & & & \\
\hline - I very rarely get embarrassed. & & & & \\
\hline $\begin{array}{l}\text { - I seem to worry more than other } \\
\text { people do. }\end{array}$ & & & & & \\
\hline $\begin{array}{l}\text { - I get impatient with people who are } \\
\text { late and keep me waiting. }\end{array}$ & & & & & \\
\hline - I dislike standing in long lines. & & & & & \\
\hline - I generally proceed with caution. & & & & & \\
\hline - I consider myself an independent person & & & & & \\
\hline $\begin{array}{l}\text { - I am very satisfied with my life just the } \\
\text { way it is. }\end{array}$ & & & & & \\
\hline - I don't like to follow the crowd. & & & & & \\
\hline $\begin{array}{l}\text { - I like to try the new products as soon } \\
\text { as they become available. }\end{array}$ & & & & & \\
\hline
\end{tabular}

\section{Data Analysis}

Analysis of covariance was performed for hypothesis H1 and for the two groups of women representing the two levels of this independent variable: marital status (divorced vs. married women) and its impact on women's impulsivity. However, analysis of variance has been used for hypotheses $\mathrm{H} 2, \mathrm{H} 3$ and $\mathrm{H} 4$ to see if there are any significant differences among women regarding their impulsivity and based upon their educational attainment, occupations and age.

\section{The Questionnaire}

The used questionnaire is the product of the efforts in the pretest and of some revisions to which the questionnaire was subjected in order to improve its wording and, appearance.

Part I of the questionnaire includes the scale used to measure women's impulsivity. Part II of the questionnaire collects demographic data about the subjects, in the following areas. women's age, education, occupation, present marital status and the number and ages of children.

(11) H. J. Eysenck and S.B.G. Eysenck, Personality Structure and Measurement. London: Routledge \& Kegal Paul, (1969)

(12) a. Ibid.

b. S.B.G. Eysenck and H.J. Eysenck, Manual of the Eysenck Personality Questionnaire, London: Hodder \& Stoughton. San Diego, ITS Publishers, (1975).

C. H.J. Eysenck and S.B.G. Eysenck, Psychoticism as a measurement, London: Routledge \& Kegan, Paul, (1976). 


\section{Hypothesis H1}

\section{Presentation and Analysis of Findings}

Hypothesis H1 suggests that divorced women will be less impulsive than married women. This hypothesis was tested using an analysis of covariance with income as a covariant. The results of this analysis show that there was a significant difference between the two groups of women regarding their impulsivity as data in Table (1) indicate and where P-values for the covariant and main effects (i.e., being divorced or married) were 0.021 and 0.000 . Further data in Table (2) indicate a significant difference between the adjusted means of women's impulsivity for both groups of women (38.11 to 33.57 respectively and where $\mathrm{p}=0.000$ ).

Based on these findings Hypothesis H1 is supported. The results of this hypothesis is consistent with previous conceptualized relationships. For example, Keith ${ }^{(13)}$ found that the traumatic experience of divorce may lead to various coping or defense mechanisms, including a longer deliberation and avoidance of acting on impulse in any future situation. Also, Levinger ${ }^{(14)}$ stated that the precarious situation of divorce could lead divorced women to longer periods of deliberation before acting upon or reacting to a given situation.

TABLE (1) Analysis of Covariance Results of Impulsivity for the two Groups of Women (Divorced and Married)

\begin{tabular}{|l|c|c|c|c|c|}
\hline $\begin{array}{c}\text { Source of } \\
\text { Variation }\end{array}$ & SS & DF & MS & F & $\begin{array}{c}\text { Significance } \\
\text { of P }\end{array}$ \\
\hline Covariant Income & & & & & 0.021 \\
\hline $\begin{array}{l}\text { Main Effects } \\
\text { Marital Status }\end{array}$ & 1328.41 & 1 & 1328.41 & 31.41 & 0.000 \\
\hline Explained & 1554.64 & 2 & 777.32 & 18.38 & 0.000 \\
\hline Residual & 13743.80 & 325 & 42.29 & & \\
\hline \multicolumn{1}{|c|}{ Total } & 15298.45 & 327 & 46.78 & & \\
\hline
\end{tabular}

TABLE (2) A Comparison of Impulsivity Mean for the two Groups of Women Adjusted for Income

\begin{tabular}{|l|c|c|c|}
\hline Group of Women & Unadjusted Mean & Adjusted Mean & $\mathrm{P}$ \\
\hline Married & 38.13 & 38.11 & 0.000 \\
\hline Divorced & 33.52 & 33.57 & \\
\hline
\end{tabular}

\section{Hypothesis $\mathrm{H} 2$}

Hypothesis H2 suggests that women's impulsivity will vary according to their educational attainment. A one-way analysis of variance was performed for four educational levels of women as independent variable and the dependent variable of impulsivity. The F-test yielded a value of 16.50 which is significant where $\mathrm{P}=0.000$ as data in Table (3) indicate. Further, data in Table (4) indicate a significant difference between the adjusted means of women's impulsivity and for four levels of education

(13) P. Keith, change in Live Areas and Well Being, in: E. Powers, W. Goudy, and P. Keith (ed.), Older Workers in Small Towns. Boston: Kluwer, (1985).

(14) Levinger, op. cit., 21-47. 
(33.94 to 34.97 to 39.76 to 37.87 respectively and where $\mathrm{P}=0.002$ ). Based on this finding, $\mathrm{H} 2$ is supported. The results of this hypothesis is consistent with the previous conceptualized relationship. Hirschman ${ }^{(15)}$ suggested that people impulsivity or innovativeness may be correlated or influenced by such variables as educational attainment, occupational status and marital status as well. Therefore, it is likely to expect that different educational levels will result in different degrees of women's impulsivity as the results of this study suggest.

TABLE (3) Analysis of Variance Results of Impulsivity of Women According to Their Educational Levels

\begin{tabular}{|l|c|c|c|c|c|}
\hline Source of Variation & SS & DF & MS & F & P \\
\hline $\begin{array}{l}\text { Main Effects } \\
\text { Educational level of women }\end{array}$ & 1410 & 2 & 705 & 16.50 & 0.000 \\
\hline Explained & 1410 & 2 & 705 & 16.50 & 0.002 \\
\hline Residual Total & 13888.42 & 325 & 42.73 & & \\
\hline \multicolumn{1}{|c|}{15298.45} & 327 & 46.78 & & \\
\hline
\end{tabular}

TABLE (4) A Comparison of Impulsivity Mean of Women Based on Their Educational Levels

\begin{tabular}{|l|c|c|c|c|}
\hline Educational Level & Number of Cases & Unadjusted Mean & Adjusted Mean & P \\
\hline High School & 98 & 33.95 & 33.94 & \\
\hline College Student & 56 & 35.53 & 34.97 & 0.002 \\
\hline College Graduate & 129 & 39.76 & 39.76 & \\
\hline Graduate School Attended & 44 & 38.64 & 37.87 & \\
\hline
\end{tabular}

\section{Hypothesis $\mathrm{H3}$}

Hypothesis H3 suggests that women's impulsivity will vary according to their occupational status. A one-way analysis of variance was performed for five types of occupational status of women as independent variable and the dependent variable of impulsivity. The F-test yielded a value of 3.97 which is significant where $\mathrm{P}=0.002$ as data in Table (5) indicate. Further, data in Table (6) indicate a significant difference between the adjusted means of women's impulsivity for five levels of occupational status (39.73 to 37.56 to 36.98 to 34.73 to 33.81 respectively and where $\mathrm{P}$ - value = 0.002). Based on this finding, Hypothesis $\mathrm{H} 3$ is supported. The results of this hypothesis is consistent with the conceptualized relationship, which states that women's impulsivity will vary as their occupational status varies, because impulsivity as inherited character is not a genetic constant, but rather is socially influenced by many variables such as occupation, income, education and marital status as mentioned before.

TABLE (5) Analysis of Variance Results of Women's Impulsivity According to Their Occupational Levels ${ }^{(a)}$

\begin{tabular}{|l|c|c|c|c|c|}
\hline Source of Variation & SS & DF & MS & F & P \\
\hline $\begin{array}{l}\text { Main Effects } \\
\text { Occupation }\end{array}$ & 907.43 & 5 & 181.48 & 3.97 & 0.002 \\
\hline Explained & 907.43 & 5 & 181.48 & 3.97 & 0.002 \\
\hline Residual Total & 14235.82 & 312 & 45.63 & & \\
\hline \multicolumn{1}{|c|}{ Tol } & 15143.25 & 317 & 45.77 & & \\
\hline
\end{tabular}

(a) Number of Missing Observations $=11$.

(15) Hirschman, op. cit., 1980, 283-295. 
TABLE (6) A Comparison of Impulsivity Means of Women According to Their Occupational Levels

\begin{tabular}{|l|c|c|c|c|}
\hline \multicolumn{1}{|c|}{ Occupation } & $\begin{array}{c}\text { Number of } \\
\text { Cases }\end{array}$ & $\begin{array}{c}\text { Unadjusted } \\
\text { Mean }\end{array}$ & $\begin{array}{c}\text { Adjusted } \\
\text { Mean }\end{array}$ & P \\
\hline - Professional (e.g., Teachers, Doctors, etc.) & 105 & 39.73 & 39.73 & \\
\hline - Managerial Job & 52 & 37.69 & 37.56 & 0.002 \\
\hline - Clerical job & 68 & 36.98 & 36.98 & \\
\hline - Sales & 74 & 34.73 & 34.73 & \\
\hline - Others & 28 & 33.87 & 33.81 & \\
\hline
\end{tabular}

\section{Hypothesis H4}

Hypothesis H4 suggests that women's impulsivity will vary according to their age categories. A one-way analysis of variance was performed for five age categories of women as independent variable and the dependent variable of impulsivity. The F- test yielded a value of 28.69 which is significant where $\mathrm{P}=0.000$, as data in Table (7) indicate. Also, data in Table (8) indicate a significant difference between the adjusted means of women's impulsivity for five categories of age (39.76 to 38.14 to 36.07 to 34.69 to 33.71 respectively and where $\mathrm{P}-$ value $=0.002$ ). Based on this finding, hypothesis $\mathrm{H} 4$ is supported. The results of the hypothesis is consistent with conceptualized relationship, which states that learning experience of people increases as they become older and that will affect negatively their impulsivity and consequently their behavioral patterns in the marketplace ${ }^{(16)}$

TABLE (7) Analysis of Variance Results of Impulsivity of Women According to Their Age Categories

\begin{tabular}{|l|c|c|c|c|c|}
\hline Source of Variation & SS & DF & MS & F & P-Value \\
\hline $\begin{array}{l}\text { Main Effect } \\
\text { Actual Age }\end{array}$ & 1207.40 & 1 & 1207.40 & 28.69 & 0.000 \\
\hline Explained & 1620.91 & 2 & 810.46 & 19.26 & 0.000 \\
\hline Residual & 13677.54 & 325 & 42.08 & & \\
\hline Total & 15298.45 & 327 & 46.78 & & \\
\hline
\end{tabular}

TABLE (8) A Comparison of Impulsivity Mean of Women Based on Their Age Categories

\begin{tabular}{|c|c|c|c|c|}
\hline Age Category & Number of Cases & Unadjusted Mean & Adjusted Mean & P \\
\hline $25-29$ & 59 & 38.79 & 39.76 & \\
\hline $30-34$ & & 37.86 & 38.14 & \\
\hline $35-39$ & 94 & 36.69 & 36.07 & 0.002 \\
\hline $40-44$ & 56 & 34.81 & 34.69 & \\
\hline $45+$ & 22 & 33.79 & 33.71 & \\
\hline
\end{tabular}

(16) G. Trommsdorff and H. Lamm, An Analysis of Future Orientation and Some of its Social Determinants, in: J. T. Fraser and N. Lawrences (eds.), The Study of Time. New York: Spring-Verlag, (1975) 343-361. 


\section{Discussion and Interpretation of Findings}

The general thesis of this study is that women's impulsivity varies according to their marital status, educational attainment, occupational status and age category. The expected variations are assumed to appear as a result of the various levels of learning and changing behavioral patterns that women may experience to varying degrees.

In hypothesis $\mathrm{H} 1$ to $\mathrm{H} 4$, the results of covariance and a one-way analysis of variance provide strong evidence that Jordanian women differ significantly in respect to impulsivity and according to their marital status, educational attainment, occupational status and age category as data in Tables (1) through (8) indicate.

In regard to women's impulsivity and their marital status (i.e., being divorced and married), the results of the statistical analysis have indicated that married women appear to be more impulsive than divorced women as data in Tables (1) and (2) indicate.

Similarly, the series of analysis of variance tests and adjusted means comparison performed among the four levels of women's educational attainment and impulsivity have revealed statistically significant differences among them as data in Tables (3) and (4) indicate. Further, data in Table (4) indicate that women's impulsivity increases as their educational level increases (High school: 33.94, College student: 34.97, College graduate: 39.76 and attended graduate school: 37.87$)$. With respect to women's impulsivity and their occupational status, the results of the statistical analysis have indicated significant differences among them as data in Tables (5) and (6) indicate. Furthermore, data in Table (6) indicate that women's impulsivity increases as the level of occupation status of women increases (33.81 to 34.73 to 36.98 to 37.56 to 34.73 respectively and $\mathrm{P}=0.002$ ).

Finally, with respect to women's age and its expected importance on their impulsivity, the results presented in Tables (7) and (8) have indicated statistically significant differences among them in this spread. Also, data in Table (8) indicate that women's impulsivity decreases as women become older and older (39.76 to 38.14 to 36.07 to 34.69 and 33.71 respectively and $\mathrm{P}=0.002$ ).

\section{Marketing Implications and Conclusion}

This study takes a view that the demographic factors of Jordanian women affect their impulsivity. This was largely confirmed in this study.

Indeed, this study has a number of ramifications for marketing area. First, this is the first study to identify and analyze Jordanian women's impulsivity using a national representative sample of women drawn from the various cities and towns in Jordan. Second, the most important findings of this study are concerned with investigating the interface of some demographic variables with certain personality characteristics to arrive at a framework for the analysis of the psychological and behavioral consequences of these demographic variables and their relationship to women's impulsivity. Third, the results of this study show that the demographic factors of women provide a starting point to marketing people to identify and analyze what situational factors stimulate or discourage impulse buying (e.g., point of purchase, shelf position, the nature and 
attractiveness of the package, in-store pricing promotions) for Jordanian women. Fourth, the findings of this study suggest that women from different marital status vary in their impulse buying proclivities. Fifth, it is useful to think of consumer impulsivity as a life-style trait. Sixth, this study allows the marketer to utilize knowledge of women's impulsivity to increase sales of specific items. For example, retailers must act towards attracting women to their outlets by structuring the purchasing environment in a manner that provides maximum encouragement for impulsive buying. Also, the unusual in-store environment of store may contribute to impulsive limited decision-making on the part of its many customers.

\section{Direction for Future Research}

There is insufficient data available about the behavioral patterns of Jordanian women for companies or institutions to develop profitable marketing strategies. Research is promising in this area as many conceptual relationships about women's demographics or psychographics await empirical study. For example, a possible extension of this study may be to investigate the impact of demographic variables upon Jordanian men's impulsivity. This would facilitate the determination of the behavioral patterns of a nationally representative sample of married compared to single men.

Further, the frequency of impulse buying means that in-store stimuli deserve as much attention as advertising, especially for consumer packaged goods distributed in supermarkets and drug stores. Store layout, shelf allocations to products and positioning of displays are within the control of the retailer and directly influence the in store environment. Also, work to be done to provide a certain profile for high, medium and low-impulse consumers. This may build upon previous social psychological studies to help improve understanding of how impulsive behavior varies with select demographic and life-style factors and is associated with particular shopping behavior.

Finally, some marketing variables that enhance impulse buying also need renewed attention. It is not easier than ever before for Jordanian women to buy - that much impulsively for economic reasons, and it would be useful to investigate in detail how various marketing variables (e.g., credit cards, everyday shopping) support impulsive buying and which ones exert the strongest influences. Future research needs to take across cultural and sub-cultural perspective to observe how impulse buying occurs in different sub-cultural contexts. Although buying impulses are presumed to be largely universal in nature, local market conditions, exchange paradigms and various cultural forces should impact how consumers operate on impulse. 


\section{References}

Asseal, Henry, Consumer Behavior and Marketing Action, second edition, Kent Publishing Company, (1984) 559-562.

Barrett, N., Women in the Job Market: Occupation Earnings and Career Opportunities, in: R.E. Smith (ed.), The Subtle Revolution, Washington, D.C.: The Urban Institution, (1979) 31-31.

Duncan, Amy, No-Frills, Products: An Idea Whose Time Has Gone, Business Week, June 17, (1985) 64- 67.

Eysenck, S.B.G. and Eysenck, J.H., The Place of Impulsiveness in a Dimensional System of Personality Description, Journal of Sociology and Clinical Psychology, (1977) 57-68.

Eysenck, H.J. and Eysenck, S.B.G., Personality Structure and Measurement, London: Routledge \& Kegan Paul, (1969).

Eysenck, S.B.G. and Eysenck, H.J., Manual of the Eysenck Personality Questionnaire, London: Hodder \& Stoughton. San Diego, ITS Publishers, (1975).

Hirschman, Elizabeth C., Innovativeness, Novelty Seeking and Consumer Creativity, Journal of Consumer Research, Vol. 7, December, (1980) 283-295.

Keith, P., Change in Life Areas and Well Being, in: E. Powers, W. Goudy and P. Keith (eds.), Older Workers in Small Town, Boston: Kluwer, (1985).

Kitson, C. Gay, Karen Benson Babri and Roach Joan Mary, Who Divorces and Why, Journal of Family Issues, 6(3), (1985) 255-293.

Levinger, G., A Social Psychological Perspective on Marital Dissolution, Journal of Social Issues, 32(1), (1976)21-47.

Newport, Paul John, Profits in Costoffs, Fortune, September 30, (1985) 75-77.

Rook, H. and Hock, A., Impulse Buying, Advance in Consumer Research, 10, (1983) 562-567.

Rook, W. Dennis, The Buying Impulse, Journal of Consumer Research, 14, September, (1987)189-216

Schalling, D., Psychopathic Behavior: Personality and Neuro-Psychology, paper given to the Advanced Study of Behavior, Institute of Psychopathic Behavior, Les-Arcs, France, (1975).

Sobczynski, A., Inside the Store: the Selling Never Stops, Advertising Age, March, 15, (1982) 30-33.

Stern, H., The Significance of Impulse Buying Today, Journal of Marketing, 20, (1962) 59-62.

Trommsdorff, G. and H. Lamm., An Analysis of Future Orientation and Some of Its Social Determinants, in: J.T. Fraser and N. Lawrence, (eds), The Study of Time, New York: Spring-Verlag, (1975) 343-361.

Weinberg, P. and Gootwald, W., Impulsive Consumer Buying as a Result of Emotions, Journal of Business Research, 10, (1982) 43-57.

Yankelovich, Skelly and White, Supermarket Shoppers in a Period of Economic Uncertainty, New York, Yankelovich Inc., (1982) 53. 


\section{العفوية السلو كية : دراسة عن سلوكيات المرأة الأردنية}

$$
\begin{aligned}
& \text { محمد إبر اهيم عبيدات } \\
& \text { أستاذ مساعد إنميل } \\
& \text { قسم إدارة الأعمال - كلية الاقتصاد والعلوم الإدارية }
\end{aligned}
$$

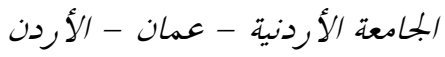

$$
\begin{aligned}
& \text { المستخلص : تهـدف هـذه الدراسـة إلى قيـاس خاصـة " العفوية السـلوكية" للمـرأة الأردنيـة } \\
& \text { وأثرها المتوقع على : أنماطها الاستهلاكية. }
\end{aligned}
$$

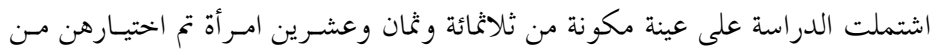

$$
\begin{aligned}
& \text { مختلف المدن والقرى الأردنية ووفق الشروط التئ تم تحديدها لهذه الدراسة. }
\end{aligned}
$$

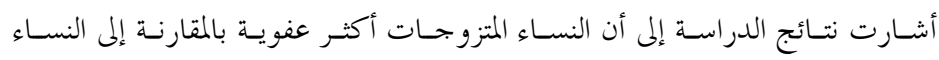

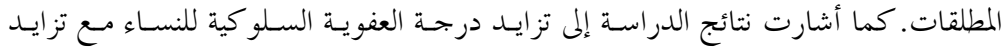

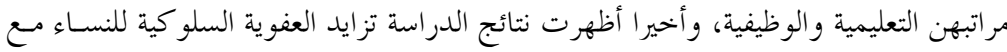

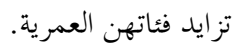

